\title{
PREDATION RISK BY GASTRONOMIC BOOM - CASE PERU
}

\author{
Aldo AlvareZ-Risco ${ }^{1}$, JAIME DElgAdo-ZEGARrA ${ }^{2}$, JAIME A. YÁÑEZ $^{3,4}$, \\ SANTIAGO DiAZ-RISCO ${ }^{5}$, SHYLA DEL-AGUILA-ARCENTALES ${ }^{6}$ \\ 1. Universidad de San Martin de Porres. Facultad de Ciencias Administrativas y Recursos \\ Humanos. Instituto de Investigación. Lima, Perú \\ 2. Universidad de San Martin de Porres. Facultad de Ciencias Administrativas y Recursos \\ Humanos. Instituto de Consumo. Lima, Perú \\ 3. Departamento de Investigación, Desarrollo e Innovación, Indetec Corp SAC. Lima, Perú \\ 4. YARI International Group, LLC, New Brunswick. New Jersey, United States \\ 5. Centro de Fertilidad Cajamarca. Cajamarca, Perú \\ 6. Universidad Nacional de la Amazonía Peruana. Facultad de Farmacia y Bioquímica. \\ Iquitos, Perú. \\ *Corresponding authore-mail: aalvarezr@usmp.pe
}

Received: $23^{\text {th }}$ March 2018, Accepted: $18^{\text {th }}$ April 2018

\begin{abstract}
The growth of tourism to Peru and the gastronomic boom with millions of people looking to taste Peruvian food is resulting in a risk of predation of natural sources necessary to make these dishes. The focus in only obtaining these ingredients can generate significant damage to the Peruvian biodiversity, so stakeholders need to develop strategies to avoid predation due to the gastronomic boom. Citizens and visitors need to play a role in protecting the natural resources and contributing to environmental sustainability.
\end{abstract}

Keywords: predation, tourism, Peru, gastronomic boom

\section{COUNTRY PROFILE}

Peru is located in western South America with an area of about 1,285,2 (Bruni \& Wesley-Schultz, 2017) sq. km, bordering the South Pacific Ocean between Chile and Ecuador and has a total land area of about 1,279,996 sq. km. According to the Central Intelligence Agency (CIA) (CIA, 2017), about $18.8 \%$ of this land is used primarily for agricultural purposes: arable land $3.1 \%$; permanent crops $1.1 \%$; permanent pasture $14.6 \%$; forests constitute about $53 \%$, and the remaining $28.2 \%$ is utilized for other activities. Peru displays a varying climatic pattern from tropical in the east, to dried desert in the west, temperate and frigid in the Andes. The country has a wide range of essential mineral resources found in the coastal and mountainous places, and Peru's coastal waters provide excellent fishing grounds (Ministry of Foreign Affairs Peru, 2015). Peru is the world's second-largest producer of silver and copper (Forbes. Peru, 2018). Other primary natural resources in the country include gold, petroleum, timber, fish, iron ore, coal, phosphate, potash, hydropower and natural gas (CIA, 2017). In 2015, the estimated population of the 
country was about 31,151,643 people (INEI, 2017). In the past decade, the poverty rate has declined considerably but remains around $20.7 \%$ (World Bank, 2018).

Peru's economy reflects its varied topography - an arid coastal region, the Andes (high sierra), the forest of the Amazon with tropical lands bordering Brazil and Colombia. Several drivers have been identified as major players in the Peruvian economy, including metal and mineral exports, a booming tourism industry, among others (CIA, 2017). Drivers of predation have been identified and can be understood as universal (Union of Concerned Scientists, 2018; Chomitz, 2007; Gibbs et al, 2010): Government action which provided incentives for the colonization of forest, increase of large business in forest areas together with incentives from government to build roads by these enterprises, increasing consumption by growing urban population, expansion of large-scale crop and pastureland; however, these drivers can vary in regional/local level and over time (Rudel et al., 2009; Boucher et al., 2011)

\section{GASTRONOMIC BOOM INCREASES TOURISM}

Inbound tourism in Peru increased lately (1.06 million of international visitors in 2002 to 3.21 million of international visitors in 2014) (Peru Reports. Tourism, 2018).

Peru's Ministry of Foreign Trade and Tourism (MINCETUR) Jose Luis Silva, noted in 2013 that "we expect to grow more than twice the world tourism growth that is between 9 and $10 \% "$. Also, he mentioned "this growth involves the arrival of around three million visitors, who will generate around the US $\$ 3.5$ billion in revenues, while this year tourism in Peru will grow over 9\%" (Andina, 2013). However, one of the significant consequences of the thriving touristic industry and the gastronomic boom in the country is the risk of predation of Peru's rich forest, with a resulting potential for deforestation and its effects. For that, proper strategies are necessary to be created to generate a balance that will ensure a coexisting booming industry and the proper use of the forest.

\section{Deforestation as a risk of gastronomic boom}

Initially, it is essential to establish differences between direct and indirect causes of deforestation (Geist \& Lambin, 2002). Direct causes are immediate actions or human activities that directly affect the forest. These causes can be grouped into categories such as agriculture expansion by commercial uses, subsistence of population, infrastructure extension and wood extraction. It has been acknowledged that agriculture in Peru has been vital and strategic in the observed changes related to the Peruvian gastronomic boom. However, more and more products are needed to sustain these changes, and in the process of obtaining them, it creates the risk of predation. Also, secondary causes are complex interactions of underlying social, political, economic, cultural, scientific and technological processes that are often distant from their area of impact. They are related to international (i.e., trade promotion agreements, commodity prices) and national (i.e., immigration process, domestic markets, governance) (Obersteiner et al., 2009).

\section{Promoting ecotourism to reduce risk of predation}

To promote environmental protection behaviors is necessary to measure and develop strategies to increase environmental protection. The first step must be to use environmental literacy scales to measure and monitor advances. Environmental literacy (EL) is critical to meet current and emerging environmental challenges worldwide; although environmental education advances have begun to overcome this need, empirical research that integrally evaluates drivers of EL is critical (Stevenson et al., 2013). 
There are many scales to measure environmental issues (Bruni \& Wesley-Schultz, 2017), but one that has a significant impact on a global scale is the Biodiversity Barometer (UEBT, 2017), which is also used in Aichi Biodiversity Target 1. The Aichi Biodiversity is part of Strategic Plan for Biodiversity 2011-2020 developed by Parties to the Convention on Biological Diversity (CBD); specifically, the Target 1 establishes textually that " $B y 2020$, at the latest, people are aware of the values of biodiversity and the steps they can take to conserve and use it sustainably" (CBD, 2018).

The Biodiversity Barometer would allow improving on community education on environmental protection, which is essential as it focuses on children and adolescents. Another approach would be to improve on already existing tourism legislature and create structures that ensure that they are fully implemented. Community education is crucial, as it is a waste to create laws and have citizens with low environmental literacy, who cannot follow the rules. Therefore, as we continue to observe the gastronomic boom, plans have to be made for the future and these plans must include improvement of environmental literacy between farmer and tourism stakeholders to create sustainable tourism. Some universities are working on Environmental Literacy (EL) (Teksoz et al., 2012) and it is needed to spread and understand that a change of values is necessary to create concrete outcomes such as behaviors, developed projects to improve agricultural management and others. Media is an excellent way to spread this information to change behaviors and improve environmental literacy (Cooper, 2011).

\section{CONCLUSION}

Planning tourism in Peru must include strategies to avoid predation due to gastronomic boom and should involve citizens to play a role in care and protection of the natural resources and contribute to environmental sustainability.

\section{REFERENCES}

CIA (2017). CIA. Perú. Retrieved July 22, 2017 from https://www.cia.gov/ library/publications/resources/the-world-factbook/geos/pe.html

Ministry of Foreign Affairs Peru (2015). Ministry of Foreign Affairs Peru. Peru's mining \& metal investment guide 2014/2015, Retrieved April 2, 2015 from http://www.rree.gob.pe/promocioneconomica/ invierta/Documents/MiningGuide.pdf.

Forbes. Peru (2018). Forbes. Peru. https://www.forbes.com/places/peru/. Retrieved January 22, 2018 from http://www.mining.com/peru-set-to-become-worlds-second-largest -copper-producer-in-2016-72667/

INEI (2017). INEI. Population 2000 to 2015. Retrieved September 22, 2017 from http://proyectos.inei.gob.pe/web/poblacion/

World Bank (2018). World Bank. Peru. Retrieved January 31, 2018 from https://data.worldbank.org/country/peru.

Union of Concerned Scientists (2018). Union of Concerned Scientists. The root of the problem. Retrieved January 22, 2018 from https://www.ucsusa.org/sites/ default/files/legacy/assets/documents/global_warming/UCS_RootoftheProblem_Driversof Deforestation_FullReport.pdf.

Chomitz, K.M. (2007). At Loggerheads?: Agricultural Expansion, Poverty Reduction, and Environment in the Tropical Forests. Washington, DC: The International Bank for 
Reconstruction and Development/TheWorld Bank, 2007.

Gibbs, H.K., Ruesch, A.S., Achard, F., Clayton, M.K., Holmgren, P., Ramankutty, N., Foley, J.A., (2010). Tropical forests were the primary sources of new agricultural land in the $1980 \mathrm{~s}$ and 1990s. PNAS August 31, 2010.

Rudel, T.K., Schneider, L., Uriarte, M., Turner, B.L., DeFries, R., Lawrence, D., Geoghegan, J., Hecht, S., Ickowitz, A., Lambin, E.F., Birkeholtz, T., Baptista, S., Grau, R. (2009). Agricultural intensification and changes in cultivated areas, 1970-2005. PNAS 106: 2067520680, 2009

Boucher, D., Elias, P., Lininger, K., May-Tobin, C., Roquemore, S., Saxon, E. (2011). The Root of the Problem: What's Driving Tropical Deforestation Today? Union of Concerned Scientists. Cambridge, Massachusetts, 2011.

Peru Reports. Tourism (2018). Peru Reports. Tourism. Retrieved January 22, 2018 from https://perureports.com/tourism/

Andina (2013). Andina. Tourism in Peru to increase around 10\% in 2013. Retrieved September 22, 2017 from http://www.andina.com.pe/Ingles/noticia-tourism-in-peru-toincrease-around-10-in-2013-435621.aspx.

Geist, H., Lambin, E. (2002). Proximate causes and underlying driving forces of tropical deforestation. BioScience, 2002; 52: 143-150

Obersteiner, M., Huettner, M.M., Kraxner, F., McCallum, I., Aoki, K., Bottcher, H., Fritz, S., Gusti, M., Havlik, P., Kindermann, G., Rametsteiner, E., Reyers, B. (2009). On fair, effective and efficient REDD mechanism design. Carbon Balance and Management, 2009: 4:11.

Stevenson, K.T., Peterson, M.N., Bondell, H.D., Mertig, A.G., Moore, S.E. (2013). Environmental, institutional, and demographic predictors of environmental literacy among middle school children. PLoS One, 2013: 8(3):e59519.

Bruni, C.M., Wesley-Schultz, M.A.P. (2017). Environmental scales. Retrieved December 22, 2017, from http://www.conpsychmeasures.com/AreasofInterest.html

UEBT (2017). UEBT. Barómetro de Biodiversidad de la UEBT. Retrieved December 22, 2017, from http://ethicalbiotrade.org/dl/UEBT\%20-\%20SP\%20Barometer\%202015.pdf.

CBD. (2018). CBD. Strategic Plan for Biodiversity 2011-2020 and the Aichi Targets. Retrieved February 11, 2018, from https://www.cbd.int/doc/strategic-plan/2011-2020/ Aichi-Targets-EN.pdf.

Teksoz, G., Sahin, E., Tekkaya-Oztekin, C. (2012). Modeling Environmental Literacy of University Students. Journal of Science Education and Technology; 2012: February, Volume 21, Issue 1, pp 157-166

Cooper, C.B. (2011). Media Literacy as a Key Strategy toward Improving Public Acceptance of Climate Change Science. BioScience, 2011: 61 (3): 231-237 